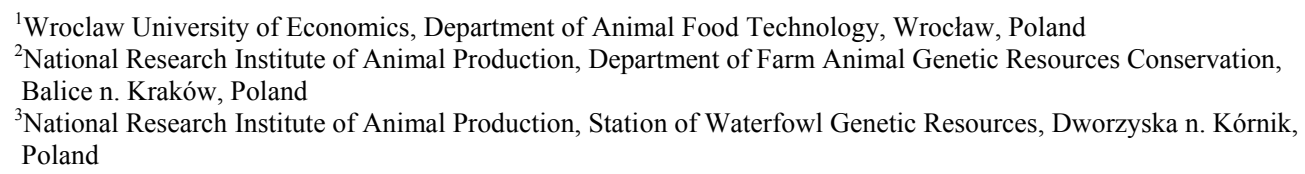

\title{
Changes in selected physicochemical parameters of breast muscles of geese from Polish conservation flocks depending on duration of the post slaughter period
}

\begin{abstract}
In four Polish conservative flocks of Suwałki (Su), Kartuzy (Ka), Kielce (Ki) and Subcarpathian (Sb) geese, registered by FAO as domestic genetic resources the mean values of qualitative traits of breast muscles $\left(\mathrm{pH}_{15^{\prime}}\right.$, $\mathrm{pH}_{30^{\prime}}, \mathrm{pH}_{45^{\prime}}, \mathrm{pH}_{24 \mathrm{~h}}$; colour parameters: $\mathrm{L}^{*}{ }_{15^{\prime}}, \mathrm{L}^{*}{ }_{30^{\prime}}, \mathrm{L}^{*}{ }_{45^{\prime}}, \mathrm{L}_{24 \mathrm{~h}}, \mathrm{a}^{*}{ }_{15^{\prime}}, \mathrm{a}^{*}{ }_{30^{\prime}}, \mathrm{a}^{*}{ }_{45^{\prime}}, \mathrm{a}^{*}{ }_{24 \mathrm{~h}}, \mathrm{~b}^{*}{ }_{15^{\prime}}, \mathrm{b}^{*}{ }_{30^{\prime}}, \mathrm{b}^{*}{ }_{45^{\prime}}, \mathrm{b}^{*}{ }_{24 \mathrm{~h}}$ and conductivity: $\mathrm{EC}_{45^{\prime}}, \mathrm{EC}_{3 \mathrm{~h}}, \mathrm{EC}_{24 \mathrm{~h}}$ ) were determined. The experimental flocks showed significant variations in the investigated parameters. The Kartuzy goose breast muscles were characterized by higher values of $\mathrm{pH}_{15^{\prime}}(6.74)$, $\mathrm{pH}_{30^{\prime}}(6.62), \mathrm{pH}_{45^{\prime}}(6.56)$ and $\mathrm{b}^{*}{ }_{15^{\prime}}$ parameter $(0.80)$ in comparison with the remaining flocks. Moreover, these muscles had the lowest $\mathrm{pH}_{24 \mathrm{~h}}(5.65)$ and values of $\mathrm{L}^{*}$ parameter $\left(\mathrm{L}^{*}{ }_{15^{\prime}}, \mathrm{L}^{*}{ }_{30^{\prime}}, \mathrm{L}^{*}{ }_{45^{\prime}}\right.$ and $\left.\mathrm{L}^{*}{ }_{24 \mathrm{~h}}\right)$ and $\mathrm{EC}_{45^{\prime}}(3.23$ $\mathrm{mS} / \mathrm{cm}$ ). The $\mathrm{pH}$ value and $\mathrm{L}^{*}$ and $\mathrm{a}^{*}$ parameters (except $\mathrm{L}^{*}{ }_{24 \mathrm{~h}}$ and $\mathrm{a}^{*}{ }_{24 \mathrm{~h}}$ ) of the analysed flocks were decreasing, and conductivity increasing together with the time post slaughter, and the rate of changes depended on the birds' origin. Greater differences between $\mathrm{pH}$ values, measured $15 \mathrm{~min}$ and $24 \mathrm{~h}$ after slaughter were stated in breast muscles from $\mathrm{Ka}(1.09)$ and $\mathrm{Su}(0.90)$ geese than from the other two flocks investigated $(\mathrm{Ki}-0.74 ; \mathrm{Sb}-0.58)$. The highest increase in conductivity (from $\mathrm{EC}_{45}$ to $\mathrm{EC}_{24 \mathrm{~h}}$ ) was affirmed in $\mathrm{Ka}$ and $\mathrm{Ki}$ muscles $(3.84 \mathrm{mS} / \mathrm{cm}$ ) and the lowest in breast muscles of $\mathrm{Sb}$ geese $(2.72 \mathrm{mS} / \mathrm{cm})$.
\end{abstract}

Keywords: geese, breast muscles, $\mathrm{pH}$, colour parameters, conductivity

\section{Zusammenfassung}

Titel der Arbeit: Veränderungen bei ausgewählten Qualitätsmerkmalen im Brustmuskelfleisch einheimischer Gänsepopulationen abhängig vom Zeitintervall nach der Schlachtung

In vier polnischen einheimischen bei der FAO erfassten erhaltenswerten Gänsepopulationen wie Suwałki (Su),

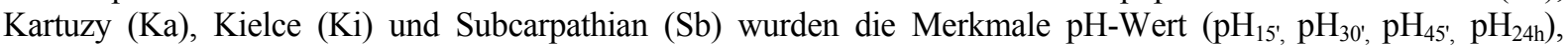
Fleischfarbe $\left(\mathrm{L}^{*}{ }_{15^{\prime}}, \mathrm{L}^{*}{ }_{30^{\prime}}, \mathrm{L}^{*}{ }_{45^{\prime}}, \mathrm{L}^{*}{ }_{24 \mathrm{~h}}, \mathrm{a}^{*}{ }_{15^{\prime}}, \mathrm{a}^{*}{ }_{30^{\prime}}, \mathrm{a}^{*}{ }_{45^{\prime}}, \mathrm{a}^{*}{ }_{24 \mathrm{~h}}, \mathrm{~b}^{*}{ }_{15^{\prime}}, \mathrm{b}^{*}{ }_{30^{\prime}}, \mathrm{b}^{*}{ }_{45^{\prime}}, \mathrm{b}^{*}{ }_{24 \mathrm{~h}}\right)$ und Leitfähigkeit $\left(\mathrm{EC}_{45^{\prime}}, \mathrm{EC}_{3 \mathrm{~h}}\right.$, $\mathrm{EC}_{24 \mathrm{~h}}$ ) ermittelt. Bei den untersuchten Populationen ergaben sich signifikante Unterschiede bei diesen Merkmalen. Ka-Gänse waren durch höhere $\mathrm{pH}-$ Werte $\left(\mathrm{pH}_{15^{\prime}}, \mathrm{pH}_{30}, \mathrm{pH}_{45^{\prime}}\right)$ und den $\mathrm{b}^{*}{ }_{15^{\prime}}$-Wert im Vergleich zu den anderen Populationen gekennzeichnet. Außerdem hatten diese Brustmuskeln die niedrigsten $\mathrm{pH}_{24 \mathrm{~h}}$ - und $\mathrm{L}$-Werte und einen niedrigeren $\mathrm{EC}_{45}$-Wert. Alle Merkmalswerte verringerten sich abhängig vom Zeitpunkt nach der Schlachtung und dem Populationsursprung. Größere Differenzen zwischen den $\mathrm{pH}_{15^{-}}$und $\mathrm{pH}_{24 \mathrm{~h}^{-}}$Werten fanden sich bei den Ka- und $\mathrm{Su}$ - im Vergleich zu Ki- und Sb-Gänsen. Die größte Zunahme der Leitfähigkeitswerte von $\mathrm{EC}_{45} \mathrm{Zu}^{\mathrm{EC}} \mathrm{C}_{24 \mathrm{~h}}$ wurde bei den Ka- und Ki-Brustmuskeln und die niedrigsten bei den Sb-Gänsen festgestellt.

Schlüsselwörter: Gans, Brustmuskel, pH-Wert, Fleischfarbe, Leitfähigkeit

\section{Introduction}

Conservation of genetically different animals, among them birds, existing in small populations and threatened with extinction is required for economic, scientific, cultural 
and historical reasons (World Watch List - FAO, 2000). From the point of view of breeding maintaining genetically diversified conservative flocks of birds is necessary to give rise to genetic variation in the selected populations (KSIĄŻKIEWICZ, 2003). These conservative flocks were used in the development of new breeding and experimental strains and synthetic lines as well as in the search for heterosis effects in commercial sets (KISIEL and KSIĄŻKIEWICZ, 2004; WAWRO et al., 2004; WOŁOSZYN et al., 2006). The world's genetic resources conservation programme currently includes 11 Polish goose populations maintained in Poland, including Suwałki geese - Su, Kartuzy geese - Ka, Kielce geese - Ki and Subcarpathian geese $\mathrm{Sb}$ (http://bioroznorodnosc.izoo.krakow.pl/gesi).

The geese from conservative flocks are characterized by good musculature and low carcass fatness as well as high dressing percentage $(\approx 65 \%)$, high percentage content of leg $(\approx 17 \%)$ and breast muscles $(\approx 20 \%)$ and also high meat quality. That is why these flocks may serve as a natural gene resource, e.g. for selection of improved qualitative traits of raw poultry meat material, which simultaneously would fulfil the requirements of an ecological product (WĘŻYK et al., 2003; ARSLAN, 2004; MAZANOWSKI, 2004).

The increase in meatiness as well as rearing conditions, nutrition, handling and slaughter related processes could affect the chemical composition of muscles, their yield, as well as the mechanism which intervenes when muscles become meat (BERRI, 2000). It is well documented that stress (feed and water deprivation, struggling, stunning and environmental conditions, like hot temperature) affects the quality of the meat, and this effect depends on both duration and intensity of the stress period (OFFER, 1991; PINGEL and KNUST, 1993; LENGERKEN et al., 1997; KÜCHENMEISTER and KUHN, 2003).

Some of the technological properties of meat can be determined by the rate of glycolysis, measured directly after animal slaughter (PINGEL and KNUST, 1993). WARRISS et al. (1989) demonstrated that characteristics of post mortem pH decline are determined by the physiological state of the animal (i.e. antemortem stress level, body temperature) at the time of stunning. As reported by SOARES et al. (2002), normal and dark, firm and dry (DFD) type meat may be affected by pre slaughter animal handling conditions such as genetics, nutrition, heat stress, transport and in particular longtime stress before slaughter.

In recent years, it has been shown that different species of birds, including geese, may be characterized by DFD- and PSE-type meat (PETRACCI et al., 2003). PSE-type poultry meat had over $30 \%$ cooking losses. An additional defect of pale meat occurs when it is used in further processing and causes up to $20 \%$ purge loss and a condition called "cracking" in which gaps appear inside the structure of the cooked meat. Therefore, PSE meat should be sorted and directed to uses where the DFD meat is not a problem (SAMS, 1999). Detection of meat with lower technological quality, leading to increased product exudate and inferior texture, is considered to be a significant problem in poultry meat processing (BARBUT, 1998; BERRI et al., 2005).

At present the chief determinants used to diagnose defects in meat are $\mathrm{pH}$ value, colour parameters and conductivity (GRZEŚKOWIAK et al., 2004). Therefore, for each species of animals there should be specified the exact lapse of time between measurements, especially in case of $\mathrm{pH}$ value. In pigs, the first measurement of $\mathrm{pH}$ value $\left(\mathrm{pH}_{1}\right)$, colour parameters $\left(\mathrm{L}_{1} *, \mathrm{a}_{1} *\right.$ and $\left.\mathrm{b}_{1}{ }^{*}\right)$ and conductivity $\left(\mathrm{EC}_{1}\right)$ is made 45 
minutes, and the second $\approx 24$ hours after slaughter. However, in poultry there are no unified standards concerning the time of measurements of the $\mathrm{pH}_{1}$ value, to identify the defects of meat.

There is no available literature concerning waterfowl, especially goose muscles. In ducks such measurements were carried out within the first 15 min (KNUST et al., 1995; SKRABKA-BŁOTNICKA et al., 2003), 20 min (BAÉZA et al., 1997) and even 45 min (ALEXIEVA et al., 1998) after slaughter. As regards $\mathrm{pH}_{2}$, all of the above mentioned authors agreed as well as by KISIEL and KSIĄŻKIEWICZ (2004) to measure it at $24 \mathrm{~h}$ post slaughter. This is the reason why we conducted an investigation on this topic. This study is a preliminary part of research aimed at determining the optimum time interval post slaughter for the measurement of $\mathrm{pH}$ value, colour parameters and conductivity of muscle tissue to identify quality defects in poultry meat. It is suggested that meat qualitative studies should include traits that had never been determined in conservative flocks of geese $(\mathrm{pH}$, colour parameters and conductivity among others) and contribute to the consumers' evaluation of meat quality.

The aim of the study was to determine changes in $\mathrm{pH}$, colour parameters and conductivity of breast muscles of geese from four conservative flocks, depending on type of flock and time after slaughter.

\section{Material and Methods}

The experiment involved 17-week-old geese from four conservative flocks ( $\mathrm{n}=12$ for each flock, with sex ratio of 1:1): Suwałki - Su; Kartuzy - Ka; Kielce - Ki and Subcarpathian - Sb (Table 1), registered in the FAO World Watch List (2000) and conserved using the in situ method as a "gene bank" at the Research Station of Waterfowl Genetic Resources in Dworzyska, belonging to the National Research Institute of Animal Production in Kraków, Poland as separate closed populations.

During the testing period geese were reared up to 6 weeks of age in a brooder house of controlled air temperature, and afterwards until 17 weeks of age they were kept on yards of restricted area, covered with straw and partially roofed.

The geese from all the flocks were fed ad libitum on the same complete feeds. This diet was given until 3 weeks of age and contained: $20.20 \%$ crude protein, $3.06 \%$ crude fat, $3.38 \%$ fibre and up to $11.59 \mathrm{MJ}$ metabolizable energy, and later - from 4 to 17 weeks of age - up to $17.60 \%$ crude protein, $2.40 \%$ crude fat, 4.08 crude fibre and $11.52 \mathrm{MJ}$ metabolizable energy per kg of feed.

All birds were weighed at 17 weeks of age using an electronic balance to an accuracy of $5 \mathrm{~g}$. Based on average live body weights $(\approx 4300 \mathrm{~g})$ of ganders and geese, 6 males and 6 females from each flock were selected for investigations. Twelve hours before slaughter, birds were only allowed access to water.

Birds were slaughtered in a local slaughterhouse according to the relevant regulations applied in the poultry industry. After slaughter the birds were manually defeathered.

The qualitative assessment of breast muscles (pectoralis superficialis) was performed based on $\mathrm{pH}$ value and colour parameters $\left(\mathrm{L}^{*}, \mathrm{a}^{*}, \mathrm{~b}^{*}\right) 15 \min \left(\mathrm{pH}_{15^{\prime}} ; \mathrm{L}^{*}{ }_{15^{\prime}}, \mathrm{a}^{*}{ }_{15^{\prime}}\right.$ and $\left.\mathrm{b}^{*}{ }_{15^{\prime}}\right), 30 \mathrm{~min}\left(\mathrm{pH}_{30^{\prime}}, \mathrm{L}^{*}{ }_{30^{\prime}}, \mathrm{a}^{*}{ }_{30^{\prime}}\right.$ and $\left.\mathrm{b}^{*}{ }_{30^{\prime}}\right)$ and $45 \mathrm{~min}\left(\mathrm{pH}_{45^{\prime}}, \mathrm{L}^{*}{ }_{45^{\prime}}, \mathrm{a}^{*}{ }_{45^{\prime}}\right.$ and $\left.\mathrm{b}^{*}{ }_{45^{\prime}}\right)$ post mortem and after $24 \mathrm{~h}$ cooling $\left(\mathrm{pH}_{24 \mathrm{~h}}, \mathrm{~L}^{*}{ }_{24 \mathrm{~h}}, \mathrm{a}^{*}{ }_{24 \mathrm{~h}}\right.$ and $\mathrm{b}^{*}{ }_{24 \mathrm{~h}}$, respectively). 
Table 1

Characteristics of investigated goose flocks (MAZANOWSKI, 2002)

(Beschreibung der untersuchten Gänsepopulationen)

\begin{tabular}{|c|c|c|c|c|c|}
\hline \multirow{2}{*}{ Flock } & \multirow{2}{*}{ Origin of geese } & \multicolumn{2}{|c|}{$\begin{array}{l}\text { Actual size of } \\
\text { population }\end{array}$} & \multirow{2}{*}{$\begin{array}{l}\text { Effective } \\
\text { size of } \\
\text { popula- } \\
\text { tion }\left(\mathrm{N}_{\mathrm{e}}\right)^{*}\end{array}$} & \multirow{2}{*}{ Characteristics } \\
\hline & & $\mathrm{n}_{+}$ & $\mathrm{n}_{\diamond}$ & & \\
\hline $\mathrm{Su}$ & $\begin{array}{l}\text { Suwałki geese - } \\
\text { old, indigenous } \\
\text { breed native to } \\
\text { northern Poland }\end{array}$ & 125 & 40 & 121 & $\begin{array}{l}\text { Mostly white plumage, sometimes piebald. Birds } \\
\text { are known for good health, resistance to } \\
\text { unfavourable environmental conditions, very good } \\
\text { meatiness and dietary efficiency. Ideally suited } \\
\text { for the creation of hybrids. }\end{array}$ \\
\hline $\mathrm{Ka}$ & $\begin{array}{l}\text { Kartuzy geese - } \\
\text { old, indigenous } \\
\text { breed native to } \\
\text { northern Poland }\end{array}$ & 123 & 40 & 121 & $\begin{array}{l}\text { Mostly white plumage, often piebald. Birds are } \\
\text { characterized by very good health, resistance to } \\
\text { unfavourable environmental conditions, very } \\
\text { good meatiness and low carcass fatness. }\end{array}$ \\
\hline $\mathrm{Ki}$ & $\begin{array}{l}\text { Kielce geese - } \\
\text { old, indigenous } \\
\text { breed native to } \\
\text { southern Poland }\end{array}$ & 128 & 40 & 122 & $\begin{array}{l}\text { White plumage, stocky and blocky body confor- } \\
\text { mation. Known for good health, resistance to } \\
\text { unfavourable environmental conditions, good } \\
\text { meatiness, low fatness and very good reproductive } \\
\text { performance. }\end{array}$ \\
\hline $\mathrm{Sb}$ & $\begin{array}{l}\text { Subcarpathian } \\
\text { geese - } \\
\text { old, indigenous } \\
\text { breed native to } \\
\text { southern Poland }\end{array}$ & 123 & 40 & 121 & $\begin{array}{l}\text { Mostly white plumage, sometimes piebald. } \\
\text { Known for good health, resistance to unfavour- } \\
\text { able environmental conditions, good meatiness, } \\
\text { low fatness and very good reproductive perfor- } \\
\text { mance. Birds are characterized by good feed } \\
\text { efficiency and can be used to produce three- or } \\
\text { four-strain hybrids with increased meatiness. }\end{array}$ \\
\hline
\end{tabular}

* Effective size of population was calculated according to the formula: $\mathrm{N}_{\mathrm{e}}=\left(4 \mathrm{~N}_{\mathrm{m}} \times \mathrm{N}_{\mathrm{f}}\right) / \mathrm{N}_{\mathrm{m}}+\mathrm{N}_{\mathrm{f}}$ (WRIGHT, 1931); where: $\mathrm{N}_{\mathrm{m}}-$ number of males; $\mathrm{N}_{\mathrm{f}}-$ number of females

The $\mathrm{pH}$ values of muscles were measured using a digital Metrohm $\mathrm{pH}$-meter 654 series (Metrohm Ltd. CH-9100 Harisau, Switzerland), equipped with a combination type of $\mathrm{pH}$ spearhead electrode - Double Pore Slim (Hamilton Company, Reno, Nevada, USA). The electrode was placed at an angle of $45^{\circ}$, midway through the investigated muscles. Values of $\mathrm{pH}$ were read from an LCD display with an accuracy of 0.01 .

The instrumental colour analysis was based on measurement of light reflected from muscle surface and later transformed into values in the CIE (1986) $\mathrm{L}^{*}, \mathrm{a}^{*}, \mathrm{~b}^{*}$ colour system. An automated Minolta Chroma Meter CR-310 (Minolta Camera Co. Ltd, 2Chome, Osaka 541 Japan) using light source $\mathrm{D}_{65}$ with $8 \mathrm{~mm}$ measuring cell was used to register $\mathrm{L}^{*}$ - lightness (assumed to be a lightness variable on a scale from 0 for an ideal black to 100 for an ideal white), $a^{*}$ - redness (represented the degree of redness if positive or greenness - if negative) and $b^{*}$ - yellowness (represented the degree of yellowness - if positive or blueness - if negative) values. Before measurements the apparatus was calibrated according to the white reference standard: $Y=94.2 ; \mathrm{x}=0.313$; $\mathrm{y}=0.324$.

Muscle conductivity $(\mathrm{mS} / \mathrm{cm})$ was measured $45 \mathrm{~min}-\mathrm{EC}_{45^{\prime}}\left(\right.$ at $\left.30.13{ }^{\circ} \mathrm{C} \pm 1.45^{\circ} \mathrm{C}\right) ; 3 \mathrm{~h}$ $-\mathrm{EC}_{3 \mathrm{~h}}$ (at $20.85^{\circ} \mathrm{C} \pm 1.33^{\circ} \mathrm{C}$ ) post mortem as well as after $24 \mathrm{~h}$ cooling $-\mathrm{EC}_{24 \mathrm{~h}}$ (at $4.65{ }^{\circ} \mathrm{C} \pm 1.59^{\circ} \mathrm{C}$ ) using a gun conductivity probe LF-PT-Star CPU (Ingenieurbüro Rudolf Matthäus Co. Ltd., Klausa, Germany). The stainless steel electrodes of the conductivity probe (diameter of each electrode $=6.5 \mathrm{~mm}$ and distance between electrodes $=10.0 \mathrm{~mm}$ ) were placed at an angle of $90^{\circ}$, midway through the investigated muscles. 
The temperature of muscles, in the middle of conductivity measurement, was registered using a spearhead thermometer linked to an LF-PT Star CPU probe. Values of conductivity and temperature were read simultaneously from an LCD display with an accuracy of $0.01\left(\mathrm{mS} / \mathrm{cm}\right.$ and $\left.{ }^{\circ} \mathrm{C}\right)$.

Statistical analyses (StatSoft, Inc., 2001, STATISTICA data analysis software system, version 7.1) included:

- calculation of the arithmetic means $(\bar{x})$ and standard deviations (sd) of the investigated traits;

- determination of the significance of differences between means for the investigated traits in analysed kinds of flocks as well as between particular investigated parameters of muscles, measured at different times after goose slaughter, within individual flocks were determined by Duncan's multiple range test. Differences were considered as significant at the level of 0.05 and 0.01 ;

- analysis of variance (ANOVA) using a one-factor design with four or three levels respectively, according to the linear model $Y_{i j}=\mu+A_{j}+e_{i j}$, where: $Y_{i j}$ - value of trait; $\mu$ - overall mean; $A_{j}$ - effect of $j^{\text {th }}$ kind of flock or particular parameters determined at different times after birds' slaughter within analysed flocks; $\mathrm{e}_{\mathrm{ij}}$ - random observation error.

\section{Results}

In the investigated flocks the average $\mathrm{pH}_{15}$, values of the goose breast muscles were similar and ranged from $6.52(\mathrm{Ki})$ to $6.74(\mathrm{Ka})$. The $\mathrm{pH}_{30}$, of breast muscles from $\mathrm{Ka}$ geese was significantly $(\mathrm{P} \leq 0.01)$ higher (6.62) than in $\mathrm{Sb}$ geese (6.33). The $\mathrm{pH}_{30^{\prime}}$ values of muscles of the two remaining flocks ( $\mathrm{Ki}$ and $\mathrm{Su}$ ) were similar (Table 2). The $\mathrm{pH}$ muscles measured $45 \mathrm{~min}$ and $24 \mathrm{~h}$ after slaughter varied according to goose flock. Higher $\mathrm{pH}_{45^{\prime}}$ of breast muscles $(\mathrm{P} \leq 0.01)$ was characteristic of $\mathrm{Ka}(6.56)$ and $\mathrm{Ki}(6.45)$ than $\mathrm{Su}(6.20)$ as well as $\mathrm{Ka}$ than $\mathrm{Sb}(6.28)$. The $\mathrm{pH}_{24 \mathrm{~h}}$ values ranged from $5.65(\mathrm{Ka})$ to $5.96(\mathrm{Sb})$, with significant differences $(\mathrm{P} \leq 0.01)$ between $\mathrm{Sb}$ and $\mathrm{Ka}(0.31), \mathrm{Su}(0.22)$ and $\mathrm{Ki}(0.18)$ flocks (Table 2).

Table 2

The value of $\mathrm{pH}$ and conductivity (EC) of breast muscles of 17-week-old geese from four conservative flocks (Der pH-Wert und die Leitfähigkeit (EC) der Brustmuskeln 17-Wochen alter Gänse der vier Versuchsgruppen)

\begin{tabular}{|c|c|c|c|c|c|c|c|c|}
\hline \multirow{2}{*}{ Flock } & & \multicolumn{4}{|c|}{$\mathrm{pH}$} & \multicolumn{3}{|c|}{$\mathrm{EC}[\mathrm{mS} / \mathrm{cm}]$} \\
\hline & & $\mathrm{pH}_{15^{\prime}}$ & $\mathrm{pH}_{30^{\prime}}$ & $\mathrm{pH}_{45^{\prime}}$ & $\mathrm{pH}_{24 \mathrm{~h}}$ & $\mathrm{EC}_{45^{\prime}}$ & $\mathrm{EC}_{3 \mathrm{~h}}$ & $\mathrm{EC}_{24 \mathrm{~h}}$ \\
\hline $\mathrm{Su}$ & $\begin{array}{c}\overline{\bar{x}} \\
\mathrm{sd}\end{array}$ & $\begin{array}{r}\text { A'}^{\prime} 6.64 \\
0.11\end{array}$ & $\begin{array}{r}\text { A' }^{\prime} 6.51 \\
0.25\end{array}$ & $\begin{array}{c}\mathrm{A}^{\prime} 6.20^{\mathrm{B}} \\
0.16\end{array}$ & $\begin{array}{c}\mathrm{B}^{\prime} 5.74^{\mathrm{B}} \\
0.16\end{array}$ & 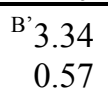 & $\begin{array}{c}\mathrm{A}^{\prime} \mathrm{b}^{\prime} 5.97^{\mathrm{Aa}} \\
0.71\end{array}$ & $\begin{array}{r}\text { A'a' }^{\prime} 6.75 \\
0.82\end{array}$ \\
\hline $\mathrm{Ka}$ & $\begin{array}{l}\bar{x} \\
\mathrm{sd}\end{array}$ & $\begin{array}{r}\mathrm{A}^{\prime} 6.74 \\
0.14\end{array}$ & $\begin{array}{c}\mathrm{A}^{\prime} 6.62^{\mathrm{A}} \\
0.06\end{array}$ & $\begin{array}{c}\mathrm{A}^{\prime} 6.56^{\mathrm{AC}} \\
0.07\end{array}$ & $\begin{array}{c}\mathrm{B}^{\prime} 5.65^{\mathrm{B}} \\
0.15\end{array}$ & $\begin{array}{r}{ }^{\prime} 3.23 \\
0.44\end{array}$ & $\begin{array}{c}\mathrm{A}^{\prime} \mathrm{D}^{\prime} 5.40^{\mathrm{b}} \\
0.38\end{array}$ & $\begin{array}{c}\mathrm{A}^{\prime} \mathrm{C}^{\prime} 7.06^{\mathrm{a}} \\
1.16\end{array}$ \\
\hline $\mathrm{Ki}$ & $\begin{array}{c}x \\
\text { sd }\end{array}$ & $\begin{array}{r}\mathrm{A}^{\prime} 6.52 \\
0.13\end{array}$ & $\begin{array}{r}\mathrm{A}^{\prime} 6.48 \\
0.15\end{array}$ & $\begin{array}{c}\mathrm{A}^{\prime} 6.45^{\mathrm{A}} \\
0.10\end{array}$ & $\begin{array}{c}{ }^{\prime}{ }^{\prime} 5.78^{\mathrm{B}} \\
0.15\end{array}$ & $\begin{array}{r}\text { B' }^{\prime} .43 \\
0.31\end{array}$ & $\begin{array}{c}\mathrm{A}^{\prime} \mathrm{D}^{\prime} 5.18^{\mathrm{B}} \\
0.50\end{array}$ & $\begin{array}{c}\mathrm{A}^{\prime} \mathrm{C}^{\prime} 7.26^{\mathrm{A}} \\
0.41\end{array}$ \\
\hline $\mathrm{Sb}$ & $\begin{array}{c}\bar{x} \\
\mathrm{sd}\end{array}$ & $\begin{array}{r}\mathrm{A}^{\prime} 6.54 \\
0.20\end{array}$ & $\begin{array}{c}\mathrm{A}^{\prime} 6.33^{\mathrm{B}} \\
0.17\end{array}$ & $\begin{array}{c}\mathrm{A}^{\prime} 6.28^{\mathrm{D}} \\
0.19\end{array}$ & $\begin{array}{c}\mathrm{B}^{\prime} 5.96^{\mathrm{A}} \\
0.09\end{array}$ & $\begin{array}{r}\text { B' } 3.50 \\
0.64\end{array}$ & $\begin{array}{c}\mathrm{A}^{\prime} 5.82^{\mathrm{c}} \\
0.49\end{array}$ & $\begin{array}{c}\mathrm{A}^{\prime} 6.22^{\mathrm{Bb}} \\
0.43\end{array}$ \\
\hline
\end{tabular}

$\mathrm{EC}=$ conductivity of muscles measured $45 \mathrm{~min}, 3 \mathrm{~h}$ and $24 \mathrm{~h}$ post slaughter

Significant differences in columns between flocks at $\mathrm{P} \leq \mathrm{a}-\mathrm{d} ; \mathrm{P} \leq 0.01 \mathrm{~A}-\mathrm{D}$

Significant differences in lines between parameters within individual flocks at $\mathrm{P} \leq 0.05$ a' $-\mathrm{d}^{\prime} \mathrm{P} \leq 0.01 \mathrm{~A}^{\prime}-\mathrm{D}^{\prime}$

The effects of genotype on conductivity (EC) of muscles, measured $45 \mathrm{~min}$ after slaughter of geese were not found (Table 2). The highest $\mathrm{EC}_{3 \mathrm{~h}}$ value was noted in $\mathrm{Su}$ 
$(5.97 \mathrm{mS} / \mathrm{cm})$, and the lowest in Ki goose muscles $(5.18 \mathrm{mS} / \mathrm{cm})(\mathrm{P} \leq 0.01)$. Significant differences $(\mathrm{P} \leq 0.05)$ in the value of this parameter were noted also between $\mathrm{Su}$ and $\mathrm{Ka}$ as well as between $\mathrm{Sb}$ and $\mathrm{Ki}$ goose muscles. There were significant differences in $\mathrm{EC}_{24 \mathrm{~h}}$ between the following groups: $\mathrm{Ki}$ and $\mathrm{Sb}(\mathrm{P} \leq 0.01)$ as well as $\mathrm{Ka}$ and $\mathrm{Sb}$ $(\mathrm{P} \leq 0.05)$ (Table 2).

The analysis of colour parameters showed that higher $(\mathrm{P} \leq 0.05)$ value of $\mathrm{L}^{*}{ }_{45^{\prime}}$ parameter was characteristic of muscles from $\mathrm{Su}$ (37.94) than Ka (36.21) geese. However, the $\mathrm{L}^{*}{ }_{15}, \mathrm{~L}^{*}{ }_{30}, \mathrm{~L}^{*}{ }_{24 \mathrm{~h}}, \mathrm{~b}^{*}{ }_{15^{\prime}}$ and $\mathrm{b}^{*}{ }_{30}$ parameters of muscles from all the flocks were similar (Table 3). The origin of geese influenced the values of $b^{*}{ }_{45}, b^{*}{ }_{24 h}$ and $a^{*}$ parameters, measured at different times after slaughter. The $b^{*}{ }_{45}$ ( $(\mathrm{Ki})$ parameter was higher by $0.79(\mathrm{P} \leq 0.05)$ than in Ka goose muscles and $\mathrm{b}^{*}{ }_{24 \mathrm{~h}}$ was lower by 1.61 than in $\mathrm{Sb}$ geese $(\mathrm{P} \leq 0.05)$. The highest intensity of redness $-\mathrm{a}^{*}{ }_{15^{\prime}}$ was noted in $\mathrm{Ki}$ (18.69) and the lowest (17.42) in $\mathrm{Su}$ goose muscles $(\mathrm{P} \leq 0.01)$. Sb geese were characterized by a higher $(\mathrm{P} \leq 0.05)$ value of $\mathrm{a}^{*}{ }_{15^{\prime}}$ and $\mathrm{a}^{*}{ }_{24 \mathrm{~h}}$ parameters $(18.34$ and 18.67, respectively) than the Su goose muscles (17.42 and 17.43) (Table 3).

Table 3

Colour parameters $\left(\mathrm{L}^{*}, \mathrm{a}^{*}, \mathrm{~b}^{*}\right)$ of breast muscles of 17 -week-old geese from four conservative flocks (Fleischfarbe [L*, a*, $\mathrm{b}^{*}$ ] der Brustmuskeln 17 Wochen alter Gänse der vier Versuchsgruppen)

\begin{tabular}{|c|c|c|c|c|c|c|c|c|}
\hline \multirow{3}{*}{ Parameter } & \multicolumn{8}{|c|}{ Flock } \\
\hline & \multicolumn{2}{|c|}{$\mathrm{Su}$} & \multicolumn{2}{|c|}{$\mathrm{Ka}$} & \multicolumn{2}{|c|}{$\mathrm{Ki}$} & \multicolumn{2}{|c|}{$\mathrm{Sb}$} \\
\hline & $\bar{x}$ & $\mathrm{sd}$ & $\bar{x}$ & $\mathrm{sd}$ & $\bar{x}$ & sd & $\bar{x}$ & $\mathrm{sd}$ \\
\hline $\mathrm{L}^{*}{ }_{15}$ & 38.51 & 1.55 & $\mathrm{~A}^{\prime} 38.07$ & 1.24 & 38.80 & 1.75 & 38.73 & 1.88 \\
\hline $\mathrm{L}^{*}{ }_{30}$ & 38.32 & 1.79 & 36.88 & 1.19 & 37.91 & 1.61 & 38.21 & 1.58 \\
\hline $\mathrm{L}^{*}{ }_{45}$ & $37.94^{\mathrm{a}}$ & 1.80 & $\mathrm{~B}^{\prime} \mathrm{D}^{\prime} 36.21^{\mathrm{b}}$ & 1.13 & 37.46 & 1.74 & 37.28 & 1.59 \\
\hline $\mathrm{L}^{*}{ }_{24 \mathrm{~h}}$ & 39.22 & 3.01 & C'38.18 & 1.88 & 38.40 & 2.28 & 38.67 & 1.96 \\
\hline$a^{*}{ }_{15}$ & $\mathrm{a}^{\prime} 17.42^{\mathrm{Bb}}$ & 1.17 & 18.07 & 0.42 & $\mathrm{a}^{\mathrm{\prime}} 18.69^{\mathrm{A}}$ & 0.72 & $18.34^{\mathrm{a}}$ & 0.87 \\
\hline$a^{*}{ }_{30}$ & $16.41^{\mathrm{B}}$ & 1.28 & $17.62^{\mathrm{A}}$ & 0.88 & $\mathrm{~b}^{\prime} 17.64^{\mathrm{A}}$ & 0.71 & $18.04^{\mathrm{A}}$ & 0.64 \\
\hline$a^{*}{ }_{45}$ & $\mathrm{~b}^{\prime} 15.91^{\mathrm{B}}$ & 1.40 & $17.46^{\mathrm{A}}$ & 0.99 & $\mathrm{~b}^{\prime} 17.41^{\mathrm{A}}$ & 1.33 & $\mathrm{~b}^{\prime} 17.71^{\mathrm{A}}$ & 1.00 \\
\hline$a^{*}{ }_{24 h}$ & $\mathrm{a}^{\prime} 17.43^{\mathrm{b}}$ & 1.77 & 17.96 & 0.94 & ${ }^{a}{ }^{\prime} 18.45$ & 0.79 & ${ }^{a^{\prime}} 18.67^{\mathrm{a}}$ & 1.15 \\
\hline $\mathrm{b}^{*}{ }_{15}$, & ${ }^{b} 0.70$ & 0.14 & ${ }^{\mathrm{B}} 0.80$ & 0.17 & ${ }^{\mathrm{B}} 0.59$ & 0.12 & ${ }^{\mathrm{B}} 0.44$ & 0.10 \\
\hline $\mathrm{b}^{*}{ }_{30}$, & ${ }^{b} 0.61$ & 0.12 & ${ }^{\mathrm{B}} 0.54$ & 0.09 & $\mathrm{~B}^{\prime} 1.04$ & 0.22 & ${ }^{\mathrm{B}} 0.57$ & 0.07 \\
\hline $\mathrm{b}^{*}{ }_{45}$ & 0.97 & 0.14 & ${ }^{\mathrm{B}^{\prime}} 0.37^{\mathrm{b}}$ & 0.10 & ${ }^{\mathrm{B}} 1.16^{\mathrm{a}}$ & 0.12 & ${ }^{\mathrm{B}} 0.79$ & 0.11 \\
\hline $\mathrm{b}^{*}{ }_{24 \mathrm{~h}}$ & $\mathrm{a}^{\prime} 1.82^{\mathrm{B}}$ & 0.22 & $\mathrm{~A}^{\prime} 2.19^{\mathrm{b}}$ & 0.17 & $\mathrm{~A}^{\prime} 2.47$ & 0.21 & $\mathrm{~A}^{\mathrm{\prime}} 3.80^{\mathrm{Aa}}$ & 0.41 \\
\hline
\end{tabular}

Significant differences in lines between flocks at $\mathrm{P} \leq 0,05 \mathrm{a}-\mathrm{d} ; \mathrm{P} \leq 0.01 \mathrm{~A}-\mathrm{D}$

Significant differences in columns between parameters within flock at $P \leq 0.05$ a' $-d^{\prime} P \leq 0.01 A^{\prime}-D^{\prime}$

The influence of time from slaughter on the analysed muscle parameters was also investigated within particular flocks of geese. The values of $\mathrm{pH}$ and $\mathrm{L}^{*}$ and $\mathrm{a}^{*}$ parameters (except $\mathrm{L}^{*}{ }_{24 \mathrm{~h}}$ and $\mathrm{a}^{*}{ }_{24 \mathrm{~h}}$ ) decreased together with the lapse of slaughter time, and the type of flock affected the rate of changes. A significant decline $(\mathrm{P} \leq 0.01)$ in the $\mathrm{pH}_{15}, \mathrm{pH}_{30}$ ', $\mathrm{pH}_{45^{\prime}}$ and $\mathrm{pH}_{24 \mathrm{~h}}$ values of the investigated muscles was observed within all the flocks. Greater differences between $\mathrm{pH}$ values, measured $15 \mathrm{~min}$ and $24 \mathrm{~h}$ after slaughter, were stated in breast muscles from $\mathrm{Ka}(1.09)$ and $\mathrm{Su}(0.90)$ geese than from the two remaining flocks analysed $(\mathrm{Ki}-0.74 ; \mathrm{Sb}-0.58)$ The differences between $\mathrm{pH}$ values of breast muscles, measured 15, 30 and 45 min after slaughter within all the investigated flocks of geese were small and statistically nonsignificant (Table 2). 
Generally the values of $\mathrm{pH}_{24 \mathrm{~h}}$ ranged in all the analysed flocks from $\approx 5.6$ up to $\approx 6.0$. In spite of the differences in the investigated parameters of $\mathrm{pH}_{24 \mathrm{~h}}$, all the muscles can be considered "normal" - RFN goose meat. No differences in $\mathrm{pH}$ values, measured 15, 30 and 45 min post mortem were observed within all the investigated flocks of geese (Table 2).

The decrease in $\mathrm{pH}$ values was always followed by a significant $(\mathrm{P} \leq 0.05, \mathrm{P} \leq 0.01)$ increase in muscle conductivity in all the investigated flocks. Higher differences in conductivity (between the $\mathrm{EC}_{45^{\prime}}$ and $\mathrm{EC}_{24 \mathrm{~h}}$ value) were stated in $\mathrm{Ki}$ and $\mathrm{Ka}$ (by 3.83 $\mathrm{mS} / \mathrm{cm}$ in both flocks), and the lowest in $\mathrm{Sb}(2.72 \mathrm{mS} / \mathrm{cm})$ goose muscles (Table 2). Significant differences in lightness $\left(\mathrm{L}^{*}\right)$ occurred only in Ka muscles, where a lower $(\mathrm{P} \leq 0.01)$ value of $\mathrm{L}^{*}$ was established $45 \mathrm{~min}$. (36.21) than $15 \mathrm{~min}$ (38.07) and $24 \mathrm{~h}$ (38.18) post slaughter. Significant $(\mathrm{P} \leq 0.05, \mathrm{P} \leq 0.01)$ differences in $\mathrm{a}^{*}$ (except $\mathrm{Ka}$ muscles) and $b^{*}$ parameters were stated depending on measurement time (Table 3 ).

\section{Discussion}

The presented results showed higher $\mathrm{pH}_{15^{\prime}}, \mathrm{pH}_{30^{\prime}}$ and $\mathrm{pH}_{45^{\prime}}$ values and lower $\mathrm{pH}_{24 \mathrm{~h}}$ values of breast muscles in $\mathrm{Su}$ and $\mathrm{Ka}$ (except $\mathrm{pH}_{45^{\prime}}$ ) compared to $\mathrm{Ki}$ and $\mathrm{Sb}$ geese. The $\mathrm{pH}_{15^{\prime}}, \mathrm{pH}_{30}$ and $\mathrm{pH}_{45^{\prime}}$ values suggested that some muscles with the highest $\mathrm{pH}$ can be the DFD-type muscles. However, the $\mathrm{pH}_{24 \mathrm{~h}}$ values of muscles from all the investigated flocks of geese were within the range from 5.65 to 5.96 that has been universally recognized as an indicator of RFN (normal) type of poultry meat. Therefore, on this basis all of the investigated breast muscles could be classified as normal type of meat. This indicates that breast muscles from all the analysed flocks of geese are free from DFD-like defect. Therefore, conservative flocks of geese reveal large usefulness for production of valuable raw material. MAZANOWSKI and KISIEL (2004) reported lower $\mathrm{pH}_{15}$, values for $\mathrm{Ki}$ and $\mathrm{Sb}$ (5.8-5.9) and for $\mathrm{Ka}$ and $\mathrm{Su}$ (6.2) as well as higher $\mathrm{pH}_{24 \mathrm{~h}}$ (except $\mathrm{Sb}$ - 5.9) for $\mathrm{Ka}$ and $\mathrm{Su}$ (6.0-6.1 $\mathrm{pH}$ unit respectively) and $\mathrm{Ki}(\mathrm{pH}=5.9)$ of breast muscles from 24-week-old geese from the same flocks. The data concerning $\mathrm{pH}_{24 \mathrm{~h}}$ obtained by FARUGA and MAJEWSKA (1982) for breast muscles of Biłgorajska geese were higher (5.85-5.91) in comparison with our results for $\mathrm{Su}, \mathrm{Ki}$ and $\mathrm{Ka}$. PUCHAJDA (1991) reported values of $\mathrm{pH}_{24 \mathrm{~h}}$ of breast muscles from 17-week-old Biłgorajska and White Kołuda geese that were similar to our results. However, the ultimate $\mathrm{pH}$ values obtained by PUDYSZAK et al. (1997) for breast muscles from 17-week-old males and females of Biłgorajska (Bi) and White Italian geese from the WD-1 line (W) and their two-breed crosses $(\mathrm{Bi} \times \mathrm{W}$ and $\mathrm{W} \times \mathrm{Bi}$ ) were higher by 0.23 compared to the $\mathrm{pH}_{24 \mathrm{~h}}$ obtained in our investigations. The ultimate $\mathrm{pH}$ values of breast muscles obtained by Skrabka-Błotnicka et al. (1997) based on analysis of 4 genotypes of 17-week-old males and females of White Italian geese (WD-1, WD-3, WD-13 and WD-31) were similar $($ difference $=0.05)$ to $\mathrm{pH}_{24 \mathrm{~h}}$ found in our paper.

The rate of $\mathrm{pH}$ decline in the analysed muscles was dependent on the genotype of geese. The data obtained indicate that the glycolysis process is slightly slower in $\mathrm{Ka}$ and $\mathrm{Su}$ (higher $\mathrm{pH}_{15}$ ) than in $\mathrm{Sb}$ and $\mathrm{Ki}$ muscles. On the basis of small differences between the values of $\mathrm{pH}_{15^{\prime}}, \mathrm{pH}_{30^{\prime}}$ and $\mathrm{pH}_{45^{\prime}}$ it was affirmed that glycolysis in goose breast muscles in the first 45 min after slaughter proceeds very slowly. The higher decline of $\mathrm{pH}$, between $\mathrm{pH}_{15}$ and $\mathrm{pH}_{24 \mathrm{~h}}$ values, was observed in $\mathrm{Ka}$ and $\mathrm{Su}$ (difference 
of 1.09 and $0.90 \mathrm{pH}$ unit, respectively) than in $\mathrm{Sb}$ and $\mathrm{Ki}$ muscles (difference of 0.58 and $0.74 \mathrm{pH}$ unit, respectively). Previous studies have shown that the goose breast muscles of crossbreds derived from ganders of Kołuda (W 33) or Graylag (Gr) ancestry and Astra A geese with a $\mathrm{pH}$ of $6.10-6.20$ at 15 min post mortem $\left(\mathrm{pH}_{15}\right)$ declined by only $\approx 0.10 \mathrm{pH}$ unit at $24 \mathrm{~h}$ post mortem $\left(\mathrm{pH}_{24 \mathrm{~h}}\right)$ (MAZANOWSKI et al., 2004). Several researches have reported on the post mortem muscle $\mathrm{pH}$ decline in the muscles of other species of birds (e.g. chickens and ducks), but no comparable information was found on the decline in goose pH. SMITH and FLETCHER (1992) reported that Pekin duckling Pectoralis muscle $\mathrm{pH}$ declined from 6.25 at 25 min post mortem to $5.96,5.71$ and 5.66 at 1,2 and $24 \mathrm{~h}$ post mortem, respectively. Taking into consideration the lack of relevant standards concerning the time of measurement of $\mathrm{pH}_{1}$ value in goose muscles, the present authors, based on the experiment performed, suggest that the first measurement of this parameter can be carried out at 15, 30 and 45 min after slaughter of birds. However, for technical reasons (longer time after slaughter), we suggest that the first measurement of $\mathrm{pH}$ value $\left(\mathrm{pH}_{1}\right)$ be performed 30 or even 45 min after goose slaughter. In ducks, as reported by KNUST and PINGEL (1992) and KNUST et al. (1995), post mortem glycolysis is nearly finished $30 \mathrm{~min}$ after slaughter.

In the available literature there are no results concerning the conductivity of goose meat. Conductivity of poultry muscles was only investigated in chicken broilers (PETER et al., 1997). These authors concluded that the conductivity of breast muscles from 84-day-old male chicken broilers of the "T $451 \mathrm{~N}$ Label" line, measured $15 \mathrm{~min}$ and $24 \mathrm{~h}$ post mortem depended on the crude protein content of the feed. In the case of breast muscles from the above mentioned line of broiler chickens the $\mathrm{EC}_{15}$, values ranged from 3.35 to $3.62 \mathrm{mS} / \mathrm{cm}$ (for crude protein content of feed of 200 and 150 $\mathrm{g} / \mathrm{kg}$, respectively) and $\mathrm{EC}_{24 \mathrm{~h}}$ from 8.09 to $9.07 \mathrm{mS} / \mathrm{cm}$ (for 175 and $225 \mathrm{~g}$ crude protein per $\mathrm{kg}$ of feed, respectively). In the present study the values of conductivity of breast muscles in all experimental groups of geese - measured $24 \mathrm{~h}$ after birds slaughter $\left(\mathrm{EC}_{24 \mathrm{~h}}\right)$ - were lower from $8 \mathrm{mS} / \mathrm{cm}$ and higher from $4 \mathrm{mS} / \mathrm{cm}$. According to standards given by POSPIECH (2000) for pork's meat, the muscles are free from PSE and DFD defects. On this basis, all of the investigated muscles could be classified as normal (RFN) type of meat.

Measurements of meat colour parameters $\left(\mathrm{L}^{*}, \mathrm{a}^{*}, \mathrm{~b}^{*}\right)$ in the goose flocks studied varied, but their values did not reveal any meat defects. The results concerning the values of $\mathrm{L}^{*}{ }_{24 \mathrm{~h}}$ and $\mathrm{a}{ }_{24 \mathrm{~h}}$ parameters obtained in our experiment were lower than those reported by CHRZANOWSKA and CHEŁMOŃSKA (in MAZANOWSKI, 2004) (by $\approx 17.80$ and 1.20 respectively) for breast muscles from White Kołuda geese (Wk), Grey geese (Gr) and their two-breed crosses ( $\mathrm{Wk} \times \mathrm{Gr}$ and $\mathrm{Gr} \times \mathrm{Wk})$. Pudyszak et al. (1997) reported that the colour brightness (\%) of breast muscles (determined by the KORTZ et al. method, 1968) from 17-week-old Biłgorajska (Bi) and White Italian geese from the WD-1 line $(\mathrm{W})$ and their two-breed crosses $(\mathrm{Bi} \times \mathrm{W}$ and $\mathrm{W} \times \mathrm{Bi})$ was as follows: $10.28 \%(\mathrm{Bi}), 10.50 \%(\mathrm{~W}), 9.78 \%(\mathrm{Bi} \times \mathrm{W})$ and $10.93 \%(\mathrm{~W} \times \mathrm{Bi})$. However colour brightness (\%) established by PUCHAJDA et al. (2006) for breast muscles from 17-week old Biłogorajska (Bi) and White Kołuda (W 31) ganders amounted 7.21\% and $8.29 \%$ respectively.

The results of the present study indicate that the values of colour parameters, $\mathrm{pH}$ and conductivity of goose breast muscles differed according to the type of flock. Higher 
values of $\mathrm{pH}_{15^{\prime}}, \mathrm{pH}_{30^{\prime}}, \mathrm{pH}_{45^{\prime}}$ and $\mathrm{b}^{*}{ }_{15^{\prime}}$ parameter in the $\mathrm{Ka}$ goose muscles than in the remaining flocks were found. Moreover, these muscles were characterized by the lowest $\mathrm{pH}_{24 \mathrm{~h}}, \mathrm{~L}^{*}{ }_{15}, \mathrm{~L}^{*}{ }_{30}, \mathrm{~L}^{*}{ }_{45^{\prime}}, \mathrm{L}^{*}{ }_{24 \mathrm{~h}}$ and $\mathrm{EC}_{45^{\prime}}$ values. The $\mathrm{pH}, \mathrm{L}^{*}$ and $\mathrm{a}^{*}$ values (except $\mathrm{L}^{*}{ }_{24 \mathrm{~h}}$ and $\mathrm{a}^{*}{ }_{24 \mathrm{~h}}$ ) decreased, and conductivity increased, together with the lapse of slaughter time, and the rate of changes depended on the type of flock. The $\mathrm{pH}$ declined faster in the muscles from $\mathrm{Ka}$ and $\mathrm{Su}$ than $\mathrm{Ki}$ and $\mathrm{Sb}$ geese. The highest increase in conductivity post slaughter was affirmed in the muscles of $\mathrm{Ka}$ and $\mathrm{Ki}$ and the lowest in the muscles from $\mathrm{Sb}$ geese.

Taking into consideration the lack of relevant standards concerning the time of measurement of initial $\mathrm{pH}$ value $\left(\mathrm{pH}_{1}\right)$ in goose breast muscles, it is very hard to interpret these results. However, the values of $\mathrm{pH}$ measured 15, 30 and 45 min after slaughter of geese suggested that some muscles with the highest $\mathrm{pH}$ can be the DFDtype muscles. On the other hand, it is evident the $\mathrm{pH}_{24 \mathrm{~h}}$ values of muscles from all the investigated flocks were within the range from $5.65(\mathrm{Ka})$ to $5.96(\mathrm{Sb})$ that has been universally recognized as an indicator of the normal type of poultry meat. On this basis all of the analysed muscles could be classified as "normal" (RFN) type of meat. Generally, the present findings suggest that the first measurement of $\mathrm{pH}$ and $\mathrm{L}^{*}$ parameters may be conducted at 15,30 and 45 min after slaughter of geese. In light of the present investigations, the conductivity of goose breast muscles should be measured $24 \mathrm{~h}$ after slaughter of birds. Future studies of all types (genotypes) of geese should be conducted to work out universally harmonized standards, pointing out accurate time intervals, in which measurements of $\mathrm{pH}$, colour parameters $\left(\mathrm{L}^{*}, \mathrm{a}^{*}\right.$ and $\left.b^{*}\right)$ and conductivity of poultry muscles might be well performed.

ARSLAN, C.:

\section{References}

Effects of diets supplemented with grass meal and sugar beet pulp meal on abdominal fat acid profile and ceacal volatile fatty acids composition in geese. Revue. Méd. Vét. 155 (2004), 619-623

ALXIEVA, D.; GENCHEV, A.; DRBOHLAV, V.:

Meat quality of intensively fattened ducks-broilers. Proc. $\mathrm{X}^{\text {th }}$ European Poultry Conference, Jerusalem (1998), 641-642

BAÉZA, E.; SALICHON, M.R.; MARCHE, G.; JUIN, H.:

Effect of sex on muscular growth and on technological and organoleptic characteristics of muscovy duck pectoralis major (breast muscle). Proc. XIII ${ }^{\text {th }}$ European Symposium on the Quality of Poultry Meat, Poznań (1997), 95-100

BARBUT, S.:

Estimating the magnitude of the pale soft exudative problem in poultry. J. Misc. Foods 9 (1998), 35-49

BERRI, C.

Variability of sensory and processing qualities of poultry meat. World's Poultry Sci. J. 56 (2000), 209224

BERRI, C.; DEBUT, M.; LEBIHAN-DUVAL, E.; SANTE-LHOUTELLIER, V.; HATTAB, N.H.; JEHL, N.; DUCLOS, M.:

Technological quality of broiler breast meat in relation to muscle hypertrophy. Arch. Tierz. 48 (2005) Special Issue, 131

CIE:

Colorimetry, Commission International de l'Eclairage. Publication CIE 15.2, $2^{\text {nd }}$ ed. Viene (1986)

FARUGA, A.; MAJEWSKA, T.:

Evaluation of some production traits in the geese White Italian, Biłgorajska, their two side hybrids and Lubelska geese. Rocz. Nauk. Zoot. 9 (1982), 87-98 [in Polish]

GRZEŚKOWIAK, E.; BORZUTA, K.; STRZELECKI, J.; LISIAK, D.; ROGALSKI, J.:

Changes in selected qualitative parameters of meat in different time after slaughter. Gosp. Mięs. 5 (2004), 14-17 [in Polish] 
KISIEL, T.; KSIĄŻKIEWICZ, J.M.:

Comparison of physical and qualitative traits of meat of two Polish conservative flocks of ducks. Arch. Tierz. 47 (2004), 367-375

KNUST, U.; PINGEL, H.:

The effect of initial pH-value in duck breast and thigh muscles on other meat characteristic. Proc. XIX ${ }^{\text {th }}$ World's Poultry Congress (1992), 221-224

KNUST, U.; PINGEL, H.; LANGERKEN, G.; WICKE, M.:

Effect of stress on duck meat quality. Proc. $X^{\text {th }}$ European Symposium on Waterfowl (1995), 373-376

KORTZ, J.; RÓŻYCZKA GRAJEWSKA-KOŁACZYK, S.:

Methodical aspect of the objective determination of colour in fresh pork meat. Rocz. Nauk. Rol. s. B 3 (1968), 333-334 [in Polish]

KSIĄŻKIEWICZ, J.M.:

Comparison of reproduction and carcass traits in light type of ducks of four conservative flocks over eight generations. Arch. Tierz. 46 (2003), 377-389

KÜCHENMEISTER, U.; KUHN, G.:

Regulation of intercellular $\mathrm{Ca}^{2+}$ concentration and meat quality in pigs. Arch. Tierz. 46 (2003), 445-454

LENGERKEN V., G.; WICKE, M.; MAAK, S.:

Stressempfindlichkeit und Fleischqualität - Stand und Perspektive in Praxis und Forschung. Arch. Tierz. 40 (1997) Sonderheft, 163-171

MAZANOWSKI, A.:

Goose biodiversity as a chance to obtain new raw materials for the poultry industry. For. Drob. 2 (2004), 96-104 [in Polish]

MAZANOWSKI, A.; KISIEL, T.:

Reproductive and meat traits of geese from selected conservation flocks. Rocz. Nauk. Zoot. t. 31 (2004), 21-38 [in Polish]

MAZANOWSKI, A.; BERNACKI, Z.; KISIEL, T.:

Meat traits and meat chemical composition of crossbreds derived from ganders of Kołuda or Graylag ancestry and Astra A geese. Ann. Anim. Sci. 4 (2004), 293-308

MAZANOWSKI, A.:

Reserve and conservative flocks of geese. Wyd. IZ Kraków, B-4 (2002), 8-11 [in Polish]

NATIONAL RESEARCH INSTITUTE OF ANIMAL PRODUCTION POLAND

http://bioroznorodnosc.izoo.krakow.pl/gesi

(information concerning the number of flocks of geese an protected genetic resources conservation programme in Poland) [in Polish]

OFFER, G.:

Modeling of the formation of pale, soft and exudative meat: Effects of chilling regime and rate and extent of glycolysis. Meat Sci. 30 (1991), 157-184

PETER, W.; DANICKE, S.; JEROCH, H.; WICKE, M.; V. LENGERKEN, G.:

Influence of dietary crude protein and energy content on carcass yield and meat quality of French label type chickens. Proc. XIII ${ }^{\text {th }}$ European Symposium on the Quality of Poultry Meat, Poznań (1997), 64-68

POSPIECH, E.:

Diagnosing the qualitative deviations of meat. Gosp. Mięs. 4 (2000), 68-71 [in Polish]

PETRACCI, M.; BETTI, M.; BIANCHI, M.; CAVANI, C., PLACUCCI, G.:

Characteristics of pale and dark broiler meat. Proc. $\mathrm{XI}^{\text {st }}$ European Symposium on the Quality of Poultry Meat (1993), 353-359

PINGEL, H.; KNUST, U.:

Effect of stress on meat quality of waterfowl. Proc. Workshop on Quality and Standardization of the Water Fowl Products, Pawłowice (1993), 9-11

PUCHAJDA-SKOWROŃSKA, H.; ŁEPEK, G.; PUDYSZAK, K.; CHODAŃ, J.:

Comparison of the slaughter value and meat quality in Bilgoraj and White Koluda ${ }^{\circledR}$ W 31 ganders. Proc. XVIII ${ }^{\text {th }}$ International Poultry Symposium PB WPSA, Rogów (2006), 254-259

PUCHAJDA, H.:

The production traits and genetic parameters in conservative flock of Biłgorajska geese. Acta Acad. Agricult. Tech. Olst., Zoot. 34 (1991), 3-59 [in Polish]

PUDYSZAK, K.; PUCHAJDA, H.; FARUGA, A.:

Meat quality in the geese Biłgorajska, Italian White and their hybrids. Proc. XIII ${ }^{\text {th }}$ European Symposium on the Quality of Poultry Meat, Poznań (1997), 243-246

SAMS, A.:

Looking for solutions pale meat poor yield. Broiler Industry 62 (1999), 26-30

SKRABKA-BŁOTNICTA, T.; KSIĄŻKIEWICZ, J.; ORKUSZ, A.; WOŁOSZYN, J.; KISIEL, T.: Evaluation of normal, PSE- and DFD-like condition in drakes' muscles from three Polish flocks. Proc. $\mathrm{XVI}^{\text {th }}$ European Symposium on the Quality of Poultry Meat (2003), 399-403 
SKRABKA-BŁOTNICKA, T.; ROSIŃSKI, A.; ELIMINOWSKA-WENDA, G.; PRZYSIĘŻNA, E.; WOŁOSZYN, J.: The effect of dietary formulation supplemented with the herbal mixture on the goose breast muscle quality. Report 3: The effect on some functional and rheological properties. Arch. Geflügelk. 61 (1997), 143-146

SMITH, D.P.; FLETCHER, D.L.:

Post-Mortem biochemistry of Pekin duckling and broiler chicken Pectoralis muscle. Poult. Sci. 71 (1992), 1768-1772

SOARES, A.L.; LARA, J.A.F.; IDA, E.I.; GUARNIERI, P.D.; OLIVIO, R.; SHIMOKOMAKI, M.: Variation in the colour of Brazilian broiler breast filet. Proc. $48^{\text {th }}$ ICoMST, 2 (2002), 540-541

WARRISS, P.D., BEVIS, E.A.; ELKINS, P.J.:

The relationships between glycogen stores and muscle ultimate $\mathrm{pH}$ in commercially slaughtered pigs. Brit. Vet. J. 145 (1989), 378-383

WAWRO, K.; WILKIEWICZ-WAWRO, E.; KLECZEK, K.; BRZOZOWSKI, W.:

Slaughter value and meat quality of Muscovy dicks, Pekin ducks and their crossbreeds and evaluation of the heterosis effect. Arch. Tierz. 47 (2004), 287-299

WĘŻYK, S.; ROSIŃSKI, A.; BIELAŃSKA, H.; BACOWSKI, H.; CYWA-BENKO, J.:

A note on the meat quality of W 11 and W 33 White Kołuda geese strains. Anim. Sci. Paper. Report. 21 (2003), 191-199

WOŁOSZYN, J.; KSIĄŻKIEWICZ, J.; SKRABKA-BŁOTNICKA, T.; HARAF, G.; BIERNAT, J., KISIEL, T.: Comparison of amino acid composition of duck breast muscles from five flocks. Arch. Tierz. 49 (2006), 194-204

WORLD WATCH LIST FOR DOMESTIC ANIMAL DIVERSITY:

WRIGHT, S. FAO, UNDP, $3^{\text {rd }}$ edition (2000), 351

Evaluation in Mendelian populations. Genetics 14 (1931), 97-159

Received: 2007-03-29

Accepted: 2008-02-27

Authors:

Dr. ANDRZEJ OKRUSZEK*

Prof. Dr. habil. JANINA WOŁOSZYN

MSc. GABRIELA HARAF

MSc. AGNIESZKA ORKUSZ

Wroclaw University of Economics,

Department of Animal Food Technology,

Komandorska 118/120

53-345 Wrocław

Poland

Prof. Dr. habil. JULIUSZ KSIĄŻKIEWICZ

National Research Institute of Animal Production

Department of Farm Animal Genetic Resources Conservation

32-083 Balice n. Kraków

Poland

Dr. GRZEGORZ SZUKALSKI

Waterfowl Breeding Farm Zadrob Co.

62-070 Zakrzewo

Poland

*Corresponding author

email: andrzej.okruszek@ae.wroc.pl 